\title{
Pembibitan Durian Unggul Lokal Palopo
}

\author{
Sukriming Sapareng ${ }^{1}$, Muh. Yusuf Idris ${ }^{2}$, Intisari ${ }^{3}$, St. Maryam Yasin ${ }^{4}$, Rosnina $^{5}$ \\ 1,2,3,4,5 Fakultas Pertanian, Universitas Andi Djemma Palopo
}

\begin{abstract}
The breeders of local superior durian seeds and other superior fruit plant nurseries have been researched and produced by the Unanda Faculty of Agriculture at the Experimental Gardens and Agro technology Nurseries. The uniqueness of the nursery business is it has low competitors who make superior products based on local durian seed breeders. The annual outputs to be achieved by the PPUPIK Business Unit of Palopo Local Superior Superior Durian Seed Breeders were (1) the implementation of the neatly arranged PPUPIK Business Unit Business, (2) the availability of a good governance system, namely database of superior research and technology, database of client needs, and client satisfaction index, (3) availability of PPUPIK unit activity guidelines and the creation of a working mechanism for PPUPIK units, (4) guaranteed sources of broodstock that is produced by Unanda Palopo, and (5) generated a new entrepreneurship program from the students.
\end{abstract}

Keywords: local superior durian, nursery business, entrepreneurship program

\section{PENDAHULUAN}

Unit usaha yang dikembangkan oleh Program Studi Agroteknologi Fakultas Pertanian Universitas Andi Djemma Palopo (PSAFP UNANDA) disebut PPUPIK Penangkar Benih Durian Unggul Lokal Palopo yang selanjutnya disebut dengan PSAFP UNANDA dengan tujuan utama menyediakan dan melestariakn bibit durian unggul lokal Palopo dengan mutu yang terjamin secara berkelanjutan. Jenis usaha ini dibidik oleh Fakultas Pertanian Universitas Andi Djemma Palopo (Unanda) karena memiliki sumber daya yang sangat mumpuni dibidang teknologi tepat guna dibidang penangkar benih ataupun pembibitan durian unggul lokal.

Penangkar benih durian unggul lokal dan pembibitan tanaman buah unggul lainnya telah di riset dan diproduksi oleh Fakultas Pertanian Unanda di Kebun Percobaan dan Pembibitan Agroteknologi. Keunikan dari usaha pembibitan tersebut adalah rendahnya kompetitor yang membuat produk unggulan berbasis penangkar benih durian lokal. Hampir belum ada penangkar benih yang berspesifikasi durian unggul lokal dengan berbagai jenis varietas durian lokal Palopo, serta kemungkinan untuk mendapatkan varietas baru dari berbagai tanaman durian lokal masyarakat. Penangkar Benih Durian Unggul Lokal relatif masih rendah kompetitornya di masyarakat Kota Palopo. Hal ini dapat ditunjukkan, bahwa bibit durian unggul lokal Palopo masih sangat sulit ditemukan di masyarakat atau penjual bibit lokal. Sejauh ini hasil survey yang kami lakukan dipenjual bibit tradisional di Palopo, kami menyimpulkan bahwa produk ini relatif belum ada yang mengembangkannya skala usaha di Palopo dan sekitarnya.

Durian unggul yang cukup terkenal di Palopo Sulawesi Selatan tepatnya di sentra Palopo yang merupakan pusat pembudidayaan hortikultura adalah durian Sawerigading, durian Lalong, durian Tomalatea dan sebagian durian Otong (Thailand) seperti pada Tabel 1. Dari segi kualitas dan rasa buah durian varietas unggul Palopo tak kalah enaknya dengan durian varietas unggul Medan dan Surabaya, serta durian varietas unggul Palopo dapat bertahan cukup lama. Saat ini, durian semakin banyak dilirik orang untuk dikebunkan. Untuk pembudidayaan buah durian diperlukan benih durian untuk kelangsungan berkebun durian. Salah satu cara menghasilkan benih tanaman durian yang baik dan bermutu untuk memenuhi kebutuhan benih petani durian yaitu dengan cara penangkaran benih. Benih merupakan salah satu input utama sekaligus faktor yang cukup dominan dalam menentukan tingkat produktivitas tanaman durian. Penangkaran benih merupakan salah satu usaha 
atau yang termasuk ke dalam sub sistem hulu (upstream agribusiness). Dimana kenyataan utamanya adalah menghasilkan produk benih bersertifikat hingga menghasilkan benih yang baik.

Target luaran tahunan yang ingin dicapai dengan adanya unit usaha PPUPIK Penangkar Benih Durian Unggul Lokal Palopo adalah sebagai berikut :

a. Terselenggaranya Bisnis Unit Usaha PPUPIK yang tersusun secara rapi.

b. Tersedianya sistem tata kelola yang baik yaitu database hasil penelitan dan teknologi unggulan, database kebutuhan klien, dan indeks kepuasan klien.

c. Tersedianya pedoman kegiatan dan terciptanya mekanisme kerja unit PPUPIK.

d. Terjamin sumber indukan yang diproduksi oleh Unanda Palopo.

e. Terciptanya wirausaha baru dari mahasiswa.

\section{METODE PELAKSANAAN}

\section{A. Bahan Baku}

Untuk biji durian yang dijadikan benih sebagai entris bawah, pengadaannya dilakukan pada musim durian. Harga persak (karung) untuk biji durian adalah Rp 100.000,-. Biji durian dibeli dari penjual durian disekitar Kota Palopo yang menjadi mitra dengan didatangkan langsung oleh penjual durian langganan, namun terkadang juga biji durian dijemput langsung menggunakan kendaraan operasional. Standar biji durian yang baik untuk bakal benih atau bibit adalah segar dan tua, tidak kisut, serta tidak terserang hama dan penyakit. Sedangkan entris atas diambil dari pohon indukan yang di Perkebunan pembibitan yaitu varietas Sawerigading dan Otong.

\section{B. Produksi}

Proses produksi dimulai dengan melakukan persemaian yang berlangsung di ruang terbuka. Sebelum melalukan persemaian terlebih dahulu persiapan lahan untuk penempatan bakal benih dan bibit durian nantinya. Dalam sebulan proses okulasi dilakukan hanya 22 hari. Jumlah benih atau bibit yang diokulasikan sekitar 190 dalam sehari.
Jumlah bibit yang diokulasi setiap bulannya kurang lebih 5.700 bibit.

\section{Proses Produksi}

Untuk menghasilkan bibit durian yang berkualitas tentu membutuhkan bahan baku berkualitas. Adapun proses pembuatan benih dan bibit durian unggul lokal Palopo (Gambar 1), sebagai berikut:

1. Hal yang pertama yang dilakukan adalah membersihkan biji durian dari sisa-sisa daging buahnya yang menempel, lalu dijemur.

2. Setelah itu biji durian dikecambahkan selama kurang lebih 1 bulan.

3. Selanjutnya biji durian ditanam di lahan dengan tanah yang sudah digemburkan, lalu diberikan pupuk kandang.

4. Umur 2 minggu biji dipindahkan ke polibag.

5. Umur 3-4 bulan benih diokulasi. Cara okulasi yaitu; kulit batang bawah disayat melintang, tepat di atas matanya. Pilih mata tunas berjarak $20 \mathrm{~cm}$ dari permukaan tanah. Kulit dikupas sepanjang 2-3 cm. Kemudian mempersiapkan mata tunas batang atas (ranting pohon) yang tidak terlalu tua. Batang atas disayat bentuk perisai. Kemudian ditempelkan di batang bawah yang sudah disayat. Kemudian diikat menggunakan plastik es dan dibungkus.

6. Setelah itu diberikan pupuk cair NPK dan organik. Tiap bulan penyemprotan hama dilakukan dengan menggunakan Pestisida Regent.

7. Pada umur 5 bulan, bibit siap dipasarkan.

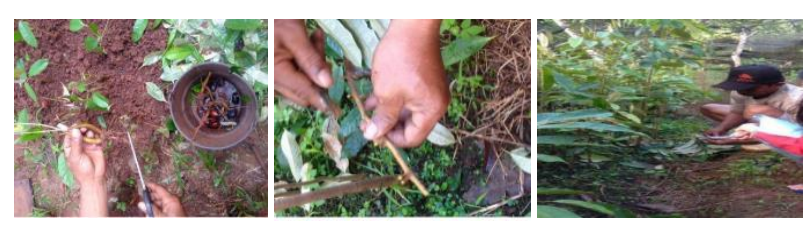

Gambar 1. Bahan dan proses okulasi bibit durian

\section{Manajemen}

Pola manajemen dan struktur manajemen unit PPUPIK Penangkar Benih Durian Unggul Lokal Palopo dapat dilihat pada Gambar 2. Unit ini berada di bawah koordinasi direktur unit PPUPIK. Dari struktur tersebut dapat dilihat bahwa 
perencanaan produksi difokuskan pada dua hal pokok, yaitu proses produksi dan pemasaran.

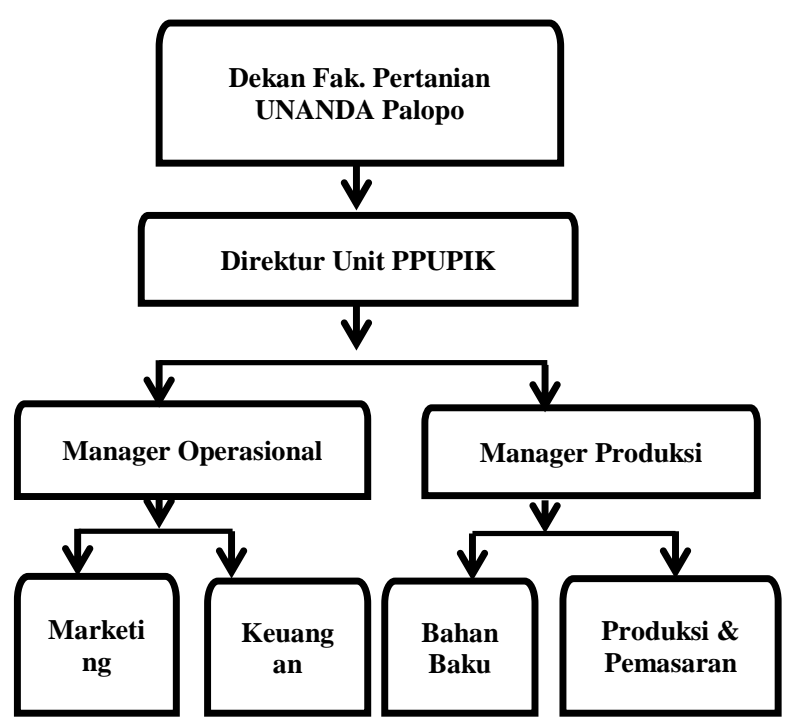

Gambar 2. Stuktur organisasi PPUPIK PSAFP UNANDA

\section{E. Pemasaran}

Produk unit IbKIK Penangkar Benih Durian Unggul Lokal Palopo akan berfokus pada pendistribusian untuk kebutuhan lokal sekitar lokasi unit PPUPIK di sekitar Kampus Unanda Palopo. Fokus selanjutnya didistribusikan ke kotakota besar yang ada di Sulawesi Selatan, seperti Makassar, Belopo, Masamba, Soroako dan Tanah Toraja. Diproyeksikan ada 6 (enam) alur pemasaran yang akan dilakukan unit PPUPIK Penakar Benih Durian Unggul Lokal Palopo ini. Untuk 5 (lima) alur pertama, fokus pemasaran pada daerah sekitar produsen yang masih dapat dijangkau langsung oleh divisi marketing, sedangkan alur terakhir adalah sasaran pasar luar kota yang memerlukan jasa/agen penjual bibit tanaman buah.

\section{F. Sumber Daya Manusia}

Sumberdaya manusia yang dibutuhkan untuk mendukung optimalitasi PPUPIK ini adalah tim dosen Universitas Andi Djemma Palopo dengan bidang keahlian dan fokus penelitian yang dilakukan selama ini adalah dalam bidang durian, sertifikasi benih, manajemen dan marketing. Selain itu, akan didukung tim operasional yang sudah terampil, dan sudah berpengalaman melakukan pembuatan pembibitan durian unggul lokal
Palopo dalam 2 tahun terakhir ini. Selain itu, SDM yang akan dilibatkan dalam PPUPIK ini adalah para peneliti-peneliti, baik dari kalangan dosen, maupun mahasiswa. Oleh karena pengalaman dan kemampuan SDM dalam pembibitan durian unggul lokal Palopo yang ada masih sangat terbatas, maka akan dilakukan pengembangan secara berkelanjutan sesuai dengan kebutuhan dan kemampuan finansial dari PPUPIK ini.

\section{HASIL DAN PEMBAHASAN}

\section{A. Terbentuknya Unit Usaha PPUPIK}

Telah terbentuk unit usaha PPUPIK dan telah berjalan manajemennya berupa usaha pembibitan durian unggul lokal palopo, spanduk dan adanya kantor pemasaran.

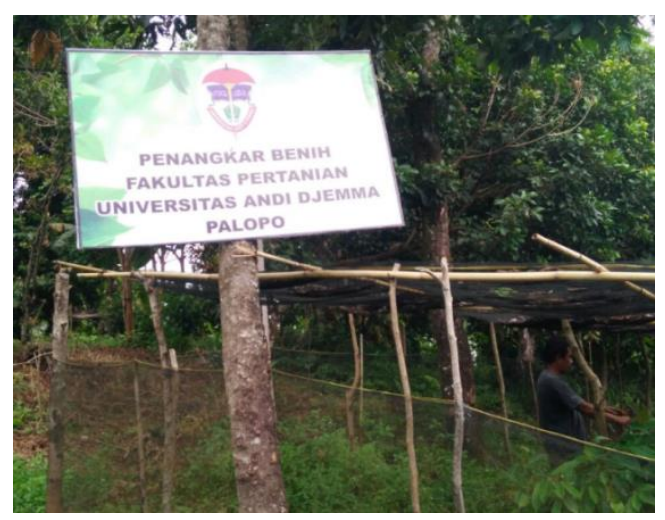

Gambar 3. Lokasi produksi bibit durian unggul lokal Palopo

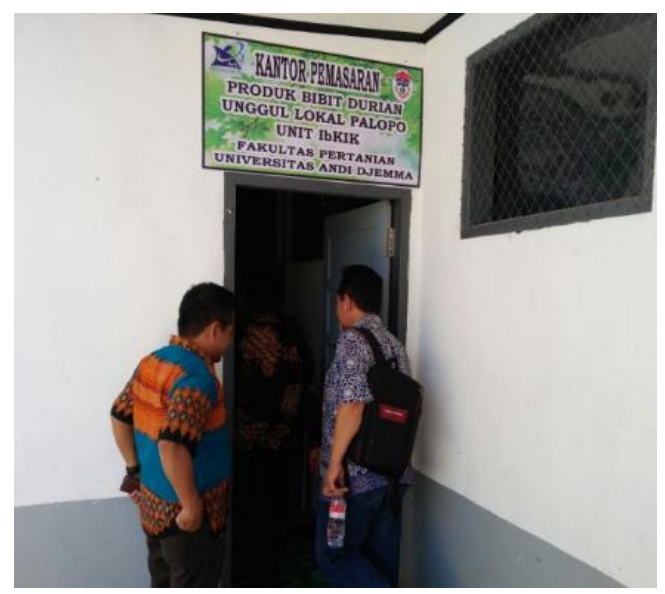

Gambar 4. Kantor Pemasaran Bibit Durian Unggul Lokal Palopo 


\section{B. Terlaksana praktik lapang dan pelatihan untuk} Mahasiswa

Telah terlaksana pelatihan dan praktik lapang yang diikuti oleh mahasiswa Agroteknologi tentang cara melakukan okulasi bibit durian unggul lokal Palopo.

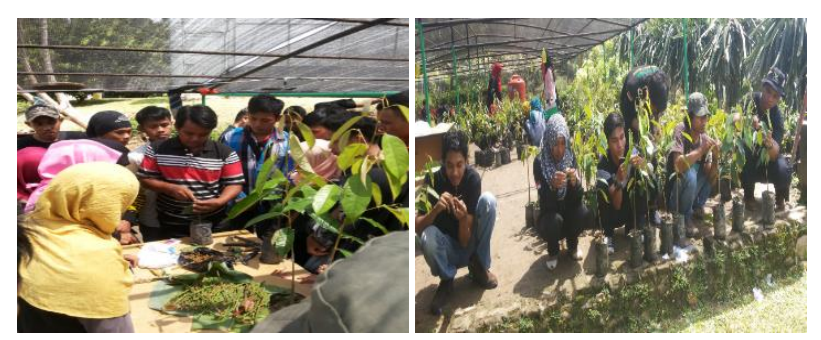

Gambar 5. Pelatihan dan PKL yang dilaksanakan di lokasi pembibitan

C. Tersedianya Bibit Durian Unggul Lokal Palopo

Unit usaha PPUPIK Fakultas Pertanian Universitas Andi Djemma Palopo, telah menyediakan dan menjual bibit Durian Unggul Lokal Palopo, yaitu Varietas Saweringading, Tomalatea, Lalong dan Othong.
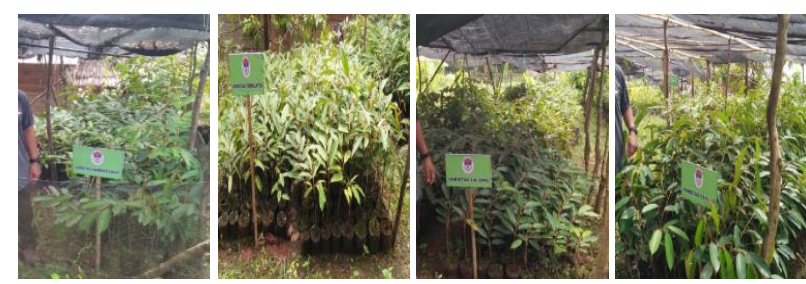

Gambar 6. Varietas yang tersedia di Unit Usaha PPUPIK Unanda

\section{KESIMPULAN}

a. Telah terbentuk kegiatan pengabdian dengan pembentukan manajemen PPUPIK Pembibitan Durian Unggul Lokal Palopo.

b. Telah dilakukan pelatihan dan praktik lapang yang diikuti oleh Mahasiswa dan Alumni yang berminat melakukan bisnis pembibitan tanaman durian.

c. Telah diproduksi dan tersedia bibit unggul lokal Palopo di Unit Usaha PPUPIK Fakultas Pertanian, yaitu Varietas Sawerigading, Tomalatea, Lalong dan Othong.

\section{UCAPAN TERIMA KASIH}

Ucapan terima kasih kami tujukan kepada seluruh teman yang telah membantu terlaksananya kegiatan pengabdian ppupik, khususnya ditujukan kepada Direktorat Riset Pengabdian Masyarakat DIKTI yang telah memberikan pendanaan dan juga Tim LP2M UNANDA Palopo yang telah memfasilitasi sehingga pengabdian kepada masyarakat dapat terlaksana dengan baik. 